\title{
7. The Fate of Crater Mountain: Forest Conservation in the Eastern Highlands of Papua New Guinea
}

\section{PAIGE WEST AND ENOCK KALE}

\section{Introduction}

Papua New Guinea's (PNG's) Crater Mountain Wildlife Management Area (CMWMA), a conservation-as-development project that began informally in the late 1970s - early 1980s and that was solidified by national and international conservation policies and practices in the 1990s, effectively ceased to exist in its original form in March 2005. The CMWMA, the oldest Wildlife Management Area (WMA) in the country, was a 2,700 square kilometre area located at the borders of Eastern Highlands, Simbu (Chimbu) and Gulf provinces. The area that the CMWMA encompassed is home to the Gimi and Pawaia peoples who believe that their day-to-day lives and social relations with the living and dead bring their forests and the plants and animals in them into being. The lands that the CMWMA encompassed matter to Gimi and Pawaia because they sustain them and are sustained by them, because they hold and tell their history, and because they are the source and the sink for their cosmological relations with the past and the future (see Ellis 2002; West 2005b, 2006a). Although neither of these sociolinguistic groups think of the world in terms of western notions of 'value', conservation scientists, activists and practitioners saw Crater Mountain and the landscape around it as biologically valuable - 'a natural resource of 
national and global importance' (Johnson 1997: 394). They saw it as valuable for three main reasons. First, much of it is covered with forest that is highly biologically diverse with high rates of endemism. Second, the area encompassed by the WMA was large enough to cover the landscape between lowland rainforest on the Purari River and montane cloud forest on Crater Mountain, thus creating a protected area that included multiple forest systems under one project. And third, because human population densities are low around Crater Mountain, it was assumed that human-generated changes to the landscape are slight.

This chapter describes the complicated history of the CMWMA and the reasons for its decline. It is based on Paige West's research with the architects of the conservation-as-development project, the people who implemented it and carried out its day-to-day management, the scientists who conducted research within its boundaries, and its Gimi-speaking residents, as well as Enock Kale's experience as a facilitator working with Gimi communities and conservation organisations in an attempt in the early 2010 s to try to revitalise the CMWMA. ${ }^{1}$ The chapter also describes the decline of a program for training young Papua New Guinean scientists that grew out of the CMWMA and argues that even with the failure of the CMWMA this training program was an enormous conservation success for PNG.

\section{Background to the Crater Mountain Wildlife Management Area}

The CMWMA began informally with the work of David Gillison, a photographer and conservation enthusiast. David was married to anthropologist Gillian Gillison and in the 1970s and 1980s they lived with Gimi-speaking people in Ubaigubi village in Eastern Highlands Province. Gillian conducted anthropological field research concerned with gender and mythology and focused her work on Gimi women. David spent time with Gimi men, talking about initiation and trekking through the forests on hunting expeditions. During these talks and trips David 'fell in love' with New Guinea birds of paradise and began photographing them. He ultimately approached Wildlife Conservation International (what is now the Wildlife Conservation Society - WCS) with a plan to protect the habitat

\footnotetext{
$1 \quad$ Paige West is a cultural anthropologist who has worked in the Crater Mountain area since 1997 (see Ellis and West 2004; Mack and West 2005; West 2001, 2003, 2004, 2005a, 2005b, 2006a, 2006b, 2008a, 2008b; West and Brockington 2006; West and Carrier 2004; West et al. 2006). Enock Kale is a conservation biologist and a native Gimi speaker. He grew up in the CMWMA.
} 
of these birds around four villages (Ubaigubi, Herowana, Maimafu and Haia) on a landscape that crossed the boundaries of Eastern Highlands Province, Gulf Province and Chimbu Province.

The CMWMA was officially established in 1994 (Johnson 1997: 397). In October of that year the PNG Department of Environment and Conservation declared it a national WMA under the Fauna (Protection and Control) Act 1966. The Act establishes the mechanisms by which 'Wildlife Management Areas, Sanctuaries, and Protected Areas' are set up and maintained. The Act provides for a set of formal institutionalised mechanisms to regulate wildlife harvesting, possession and trade in these areas.

For an area to be gazetted a national WMA, the 'customary landowners' must provide the Department of Environment and Conservation with a 'legal description of the boundaries of their area to be gazetted', a list of 'clan leaders who will sit on the local Wildlife Management Committees', and a list of conservation rules or laws that will be used to govern the WMA (Fauna (Protection and Control) Act 1966). Since the majority of people living around Crater Mountain had, at the time of the CMWMA's inception, little knowledge of the mechanisms by which the national laws work, WCS employee Jamie James went to the area to help people establish the boundaries and determine who would sit on the legally mandated Wildlife Management Committees (Johnson 1997: 399). James targeted 'leaders' who were hand picked by David Gillison, and assumed that because David identified them as 'leaders' that they were identified by the local communities as leaders. Most of the men identified as 'leaders' by Gillison had worked with him as field assistants during his years living in Gimi-speaking villages.

The Biodiversity Conservation Network $(\mathrm{BCN})$ was the major donor for the Crater Mountain project during the period of its official inception. The largest single grant was the BCN implementation grant of US\$498,107, which was spread over a three-year period from 1995 to 1998. As a BCN partner, the WCS committed US $\$ 76,950$ in funding to the project.

$\mathrm{BCN}$ was designed to fund and study international conservation projects that linked biological conservation with economic development. The ideology behind BCN was that biodiversity as 'biological capital' is already linked to the economic 'health' of the planet.

The BCN program overview states:

Conservation efforts that ignore the economic needs of local communities are unlikely to succeed. The Biodiversity Conservation Network (BCN), a component of the Biodiversity Support Program (BSP), is an innovative USAID-funded program working in the Asia/Pacific Region to provide grants 
for community-based enterprises that directly depend on biodiversity. $\mathrm{BCN}$ is testing the hypothesis that if local communities receive sufficient benefits from a biodiversity-linked enterprise, then they will act to conserve it. (BSP 1996: iii)

$\mathrm{BCN}$ took as its premise that commodity production and economic incentives which tie people to commodity-based systems are the strategies that will promote the conservation of biological diversity. $\mathrm{BCN}$ devised what its literature refers to as the 'core hypothesis'. The BCN core hypothesis states:

If enterprise-oriented approaches to community-based conservation are going to be effective, they must: 1) have a direct link to biodiversity, 2) generate benefits, and 3) involve a community of stakeholders (BSP 1996: 1).

In effect, the hypothesis is that 'if local communities receive sufficient benefits from an enterprise that depends on biodiversity, then they will act to counter internal and external threats to that biodiversity' (BSP 1996: 1). The BCN project of hypothesis testing began in earnest with a US $\$ 20$ million commitment from USAID in 1992 and was planned to last for six and a half years, ending in March 1999. Part of that money was used to found and fund the Research and Conservation Foundation of Papua New Guinea (RCF).

The RCF, a non-governmental environmental conservation organisation officially incorporated in 1986 with the help of the WCS and the PNG Department of Environment and Conservation, administered the Crater Mountain project. David Gillison founded the RCF because of his concern over what he thought to be 'declining populations' of birds of paradise in the forests near Crater Mountain. The stated goals of RCF with regard to the CMWMA fell directly in line with the stated goals of BCN. RCF attempted to meet these goals by implementing a series of programs within the four villages located in the WMA. These programs included creating local businesses revolving around biological research, tourism and handicraft production; teaching local men and children about biological diversity and conservation; and implementing a monitoring system to measure the results of biodiversity conservation.

In addition to all of this conservation-as-development around Crater Mountain, beginning in 1987 there were scientists working on the southern side of Crater Mountain. Americans Debra Wright and Andrew Mack began the research for their $\mathrm{PhD}$ degrees in ecology by building a research station that has become known as the Sera Research Station. The Sera Research Station was a biological research station located on land held by the Toyaido people of Haia (Pawaia people). It was built between 1987 and 1994 and served as the base for most of the biological research conducted in the CMWMA. Wright and Mack worked with Pawaia and Gimi people from almost the beginning of their research. Initially, they employed local people as carriers and guides but as the station came into being and their research projects got under way, they began 
to teach local men how to help them collect data. Because of this, in addition to the other 'income-generation' projects implemented by RCF, the architects of the CMWMA also incorporated some training of male landholders so that they could serve as research assistants, carriers and guides for scientists.

\section{WCS PNG and the Development of Biological Science 'Training Courses'}

Debra Wright and Andrew Mack served as the program directors for WCS PNG from 1999 to $2007 .^{2}$ Their original mandate was to conduct 'site based conservation' at Crater Mountain, manage and maintain the Sera Research Station, develop new sites for conservation and research in PNG, and conduct scientific research that could ultimately result in conservation in the country. In addition to these duties, Wright and Mack conceptualised, designed, developed and taught a series of biological science 'training courses' for PNG nationals. This was not part of their mandated duty for WCS; it was done in addition to their extensive job requirements.

The idea for the 'training courses' began to develop before Wright and Mack began working for WCS. In 1996, Mack (who was employed by Conservation International at the time) and Wright (who was still completing her PhD) applied for funds to conduct a three-month-long biological survey in three areas near Crater Mountain (Soobo, O-Pio and Aedo). They organised the survey around four taxa (birds, mammals, reptiles and amphibians, and plants) and took one University of Papua New Guinea (UPNG) student, one National Museum employee, one Forestry Research Institute professional, and one 'landowner' for each of the four taxa. During the survey they worked to 'train' their assistants in research methods including capture, identification and specimen preparation. During that same survey season, while at the camp they built at Soobo, they invited 20 students from UPNG to join them and take part in a course on methods. Both Mack and Wright enjoyed this course and the teaching that it entailed, but they were both struck by how little the senior students from UPNG knew about research design, methodology and data analysis.

\footnotetext{
2 Since 1999 WCS has maintained an office in Goroka, the city closest to the Sera Research Station at Crater Mountain. Over the years between the founding of the Goroka office and the end of the CMWMA, the WCS PNG office became the hub of New Guinea biological research. It hosted researchers from PNG, the United States, the United Kingdom, Australia, South Africa, Brazil, Germany, Venezuela, Mexico, France and Holland. All of these researchers went through Goroka on their way to the Sera Research Station, and while in Goroka they all stayed at one of the houses rented by WCS PNG, at 'Pacific Estates', a gated neighbourhood about one mile from the city centre.
} 
Later that year Conservation International, with funding from USAID, asked Mack and Wright to conduct a rapid assessment program (RAP) survey at Lakekamu. They agreed under the condition that Conservation International fund a four-week visit from UPNG students during the course of the RAP. Conservation International agreed. Andrew Mack says:

Debra and I took it in a slightly different direction in 1996 than the traditional RAP training as was done in Latin America. Our students came from a university with weaker fundamental skill building. Therefore, we incorporated more basic skills, like making data sheets, proper note taking ... We also made the project a bit more quantitative as this had been my objection to RAP prior to joining CI. I knew about [the Conservation International RAP method] from its inception because I had been a good friend of Ted Parker. But we [Debra and Andrew] both generally felt that RAP-style surveys could be enhanced without undue effort with a little bit of sampling rigor ... getting something more than just a species list.

In their attempt to refine and revise the RAP methods, Wright and Mack realised that with the program they were developing, they could pair the research they wanted to do to create a scientific basis for conservation in PNG with the biological science training of PNG nationals.

In 1997 they did another RAP-connected four-week course near Maimafu village, and in 1998 they did two more survey trips (again using the formula of one UPNG student, one National Museum employee, one Forestry Research Institute professional and one 'landowner' for each of the four taxa surveyed). Wright says:

We began this massive training effort because students told us they didn't get any exposure to actual field research in their university training - certainly not to netting of birds and bats, trapping of mammals, etc. It was a need that we could fill. Without research skills biologists can't find out what they need to know in order to manage and sustain wildlife and ecosystems. We evolved the course each year based on post-course evaluations that asked the students what they liked and didn't like about the course, and what else they would like to see included. That's how we ended up doing alternate courses - one focused on field techniques, and one focused on project design and proposal writing. Both taught data analysis, report writing, and oral presentations. Each year we tried to hold the course in a different remote field site and we would take on between twenty-five and thirty UPNG students and conservation professionals for the four weeks. We thought it was important for us all to be living together out in the bush, as a team, working and learning together.

With these early surveys and RAP trips, Mack and Wright had been exposed to students from UPNG and felt they showed promise as researchers but needed to have some additional field-based training in methods and some additional laboratory-based training in analysis and statistics before they could work 
productively with visiting researchers or, more importantly, compete for international scholarships to study out of PNG for their graduate degrees. Because of this, they proposed to run a yearly course in research design, practices and analysis that would supplement the biological training students were receiving at UPNG. The course was aimed at the most capable and successful students majoring in the biological sciences and Wright, Mack with UPNG Professor Lance Hill choosing the students.

The training course ran for three years as a course only, but at the beginning of the fourth year Mack and Wright decided to add a second stage to the course. They, and Professor Hill, felt that some of the students who had taken part in the course had accomplished so much and learned so much in the course that they might be ready to conduct honours thesis work based on what they had learned. Wright wrote a grant proposal to fund a limited number of research projects to be designed and carried out by UPNG honours program students under the supervision of herself, Mack and Professor Hill. She was successful, and in 2000 they implemented a project that identified highly qualified graduates of their training courses, and offered them a position with WCS PNG as student researchers. In this position they would design a research project, carry it out, analyse the data collected and write an honours thesis. During this process they would be based in Goroka living in a house next door to the WCS PNG office and across the street from Wright and Mack.

Over the next six years a small campus developed around the WCS PNG office. We refer to it as a 'campus' because it became a kind of hub for researchers and students. Initially only people who were working at Crater Mountain came through the WCS PNG office, but by 2005 researchers who had once worked at Crater Mountain but who now had other sites in the country would stop by the WCS PNG offices and stay for a while, even if they were not going out to Crater Mountain. In addition, the Mack/Wright house, the home of the assistant director of WCS PNG and the senior national scientist, and the student dormitory house became lodging sites for visiting researchers from all disciplines. All of the researchers who moved through the WCS PNG campus were expected to spend time with the PNG students both in professional and social ways. The social world that emerged in Goroka was one that helped students develop both their research projects and their identities as scholars. It also served as the key node in the emerging network of scholars working in the CMWMA. 


\section{WCS PNG as a Conservation Success Story}

WCS PNG, as it was organised under Wright and Mack and as it was connected to the CMWMA, was a 'success story' for conservation for four main reasons. First, Wright and Mack worked against the dominant model of expatriate scientist/national scientist interaction to build a program in which national scientists began to take the lead in scientific research design. Second, they fostered collaboration between international and national researchers from different disciplines. Third, they facilitated and conducted the most current and interesting scientific research in the highlands regions of the country. And fourth, they raised significant amounts of money for research and conservation in the country. That money did not go to consultant or expatriate salaries but rather to funding students from PNG to do research.

Historically there have been two forms of interaction between expatriate scientists and national scientists in PNG. The first, and most common, is what we term 'science as labour'.

\section{Science as Labour}

From 1995 to 2000 a UPNG-trained biologist lived and worked in Maimafu village, one of the villages in the CMWMA. During this five-year period he collected data on the biological diversity in the forests around Maimafu. From 2000 to 2002 a second biologist trained at UNITECH lived in Maimafu and collected data, from 2003 to 2004 another from UPNG and from 2004 to 2006 a fourth man lived there and collected biological data. None of these men understood fully why they were collecting this data. They knew how to do it (e.g., bird flyover counts, rain meter checks, wildlife trade counts) but they did not know what the data would be used for or what kinds of questions might be asked of the data. While these men were dedicated people, their lack of scientific knowledge of the very basics of rainforest ecology mean that as far as we are concerned the volumes of data collected are patchy and incomplete at best. But, in fact, American scientists have used some of those data in order to earn their PhD degrees. To date, none of the men who worked in Maimafu have used any of the data they collected for their own degrees. This mode of operation - 'science as labour' - is the mode of operation used in PNG by many of the major international conservation organisations working there. It does nothing to build capacity in country or conserve any biological diversity. It is one of the many reasons that 'BINGOs' (big international non-governmental organisations) have such a terrible reputation in PNG. It is, simply, another form of resource extraction. Like mining, logging and fishing, outsiders come in, extract what they want and leave little behind. 


\section{Papua New Guineans as Active Participants in Science}

The second form of interaction, pioneered by anthropologist Ralph Bulmer and Ian Saem Majnep, treats Papua New Guinean nationals as active participants in the process of science, attributes scientific findings to them, and seeks to create avenues for them to become lead researchers and design research projects (Majnep and Bulmer 1977; Majnep and Bulmer 2007). WCS PNG fit this model during the Wright and Mack years. Instead of treating all people from PNG as labour, the organisation trained PNG nationals as scientists and local landholders as research assistants. Since 2001, Paige West has interviewed 26 nationals working in conservation in PNG for her ongoing research. These people work at various non-governmental organisations (NGOs) and government offices and 41 per cent of them attended one of the WCS training courses. With this, WCS PNG began to assure that the people moving up into the government and NGO offices of conservation in PNG have a solid background in their undergraduate training in the biological sciences. Because of financial constraints, the UPNG Biology Department cannot assure this.

Under the management of the Wright/Mack team, WCS PNG developed the aforementioned much-needed training programs for PNG nationals. These programs, both the biological field methods training course — in partnership with UPNG - and an additional teacher-training course that Wright developed in partnership with RCF and the University of Goroka, have contributed to the growth of national science and national science education in PNG. By developing these programs in partnership with PNG-based institutions the Wright/Mack team contributed not only to the growth of biological sciences in PNG but also to the growth of national institutional capacity.

The annual biological field methods training course, which began open only to UPNG students, now includes national participants from other conservation NGOs, national and provincial conservation-related departments, and both national museums. It has become the vanguard of science-based conservation training in PNG. Under Mack and Wright, WCS PNG also worked with many of the UPNG honours students to help them earn and win scholarships to study abroad for masters and PhD programs. In spring 2007 there were 12 honours students living in Goroka. To date, six of these students have gone on to masters programs in the United States, Australia and New Zealand. Previously, there had been ten successful honours degrees. All ten of these people went on to earn masters degrees. By 2011, the number had increased to 15, of which three were PhD candidates.

With all of this, WCS PNG built a network of national and international researchers that were connected through Andrew Mack and Debra Wright. The customary landholders around Crater Mountain came to recognise this 
network through their systems of meaning, making a patriclan (an extended family group based on patrilineal descent) with Andrew as the 'big man' and head of the family and Debra as his wife. Over the years, the Papua New Guinean students and the expatriate researchers who worked with WCS PNG became incorporated into social life around the Sera Station as Debra and Andrew's children, cousins and the like. Andrew was blamed when someone did something socially inappropriate and was lauded when someone did something that was seen as appropriate or good. These relations were instantiated through the longterm presence of some of the WCS PNG honours degree students in areas around the Sera Station and in the villages within the CMWMA. Mack was perceived as and acted as the patriclan leader and Wright was perceived as and acted as his wife. Mack came to embody the role of a highland big man in important ways and Wright came to embody the role of a mother.

None of this is to say that either Wright or Mack became, during their 20 years in PNG, fluent in or experts on local social articulations. Neither of them learned to speak the Pawaia language or the Gimi language. Neither of them actively engaged in learning the social vernaculars of the people they were working with in and around the Sera Station. In other words, they were one type of ecologist that we see globally - focused, when 'in the field', on their research, assuming that it had little or nothing to do with the local societies, so therefore less than interested in the local societies.

\section{Resource Frontiers}

While WCS PNG was working to establish its training program and to make the Sera Research Station the pre-eminent site for field-based scientific study in the country, various other international actors were also focusing on the Crater Mountain area. During the entire history of the CMWMA there has also been resource-related exploration in the area. The first mining exploration trip around Crater Mountain was in 1970, with subsequent trips in 1971, 1972, 1977, 1983, 1984, 1988, 1995, 1996 and 1997. These trips were undertaken by several different companies. All of the exploration trips after 1994 took place under the current exploration licence (EL 1115 Crater Mountain). This licence covers 'a rectangular area of $700 \mathrm{~km}$ between $6^{\circ} 39^{\prime} \mathrm{S} 144^{\circ} 56^{\prime} \mathrm{E}$ and $6^{\circ} 28^{\prime} \mathrm{S} 145^{\circ} 15^{\prime} \mathrm{E}$ and lies $50 \mathrm{~km}$ south-west of Goroka' with Crater Mountain sitting in the centre of the area (Macmin Silver Ltd 1997). With the issuing of this licence there was a revival in interest in the area around Crater Mountain and Macmin Silver Limited spent about US\$1 million on a test drill site in 1998. After locating 'a major gold bearing hydrothermal system', Macmin considered it 'prudent to defer further valuable exploration funds' from Crater Mountain (Macmin Silver Ltd 2000). The reason given for this deferral was the low value of gold on the 
world market at that time, but the 'Crater deposit' was still, at that point, termed a 'company maker' for Macmin (Macmin Silver Ltd 2000). In 2002, New Guinea Gold Corporation, a partner company to Macmin, announced its acquisition of seven new gold and copper projects in PNG that included the Crater Mountain licence (NGG 2002).

Elsewhere, West has explained in detail what happened next:

On 6 January 2004, a story in the Papua New Guinea Post-Courier reported that Macmin Silver Limited, a subsidiary of New Guinea Gold, had signed a joint venture agreement with Celtic Minerals Limited, which gave Celtic a 75 percent interest in the Crater Mountain project (Post-Courier 2004a). On 5 February 2004, New Guinea Gold issued a press release regarding the returns at Crater Mountain from a trenching program carried out in December 2003 (NGG 2004). The story was picked up by the Post-Courier and ran as a feature on the finance page on 9 February 2004 (Post-Courier 2004b). In the press release New Guinea Gold announced their application for an expanded exploration license they had filed with the PNG Department of Mining. According to the release they filed for this expanded license because Crater has such a favorable geological setting in terms of its potential for a 'major gold bearing mineralised system.' The PostCourier story announced the trenching data (9.97 grams per tonne gold in one trench) and quoted Peter McNeil, the director of New Guinea Gold, as saying that they have 'never had results of this magnitude right at the surface.' The results indicated that this was a potentially lucrative new prospect, with an extremely rich vein, which the company continually likens to the Porgera area (Macmin Silver Ltd 2000). (West 2006b: 300)

After this frenzy of press releases, later in 2004 Triple Plate Junction, a gold and mineral exploration company from the United Kingdom, partnered with Macmin and Celtic and began to carry out further exploration in the Nevera Prospect Area and in early 2005 they began working in the Nimi Prospect Area. The land encompassed by the Nimi Prospect Area (the south end of EL 1115) is held in traditional tenure by people from Maimafu, according to people from Maimafu, and on land owned by people from Herowana, according to people from Herowana, and on land owned by people from Haia, according to people from Haia. These are three of the main villages that took part in the conservationas-development project that was the CMWMA.

According to people from all of these villages, the prospectors who have visited their lands over the past 30 years have said, with each visit, that if a mine is established, people will be given roads, schools, hospitals, jobs and access to the other things that they see as development. Villagers also report that prospectors, geologists, gold buyers and the many people from other places who have flocked to the Crater Mountain area to attempt to access some of this mineral wealth say that if mining takes hold, development and cash will come quickly to the area. 
In December 2003 InterOil, an oil exploration and refining company, landed at the Sera Research Station and told researchers and customary landholders that it would begin exploration activities in three days. InterOil said this would entail cutting at least five hectares of forest and bringing 200 workers to the site. WCS PNG attempted to negotiate with InterOil in order to have it move the exploration site out of the long-term study area (the area around the Sera Station had had few human impacts in terms of hunting or harvesting since about 1987). The company initially refused to negotiate with WCS PNG, citing underlying geological concerns as the reason for its decision to drill within the WCS PNG study area. Eventually, WCS PNG negotiated with InterOil a concession for minimised impact at the drill site and one for quick drilling (the company agreed to be out of the area by April 2004). After these negotiations, InterOil set up a 'camp' at the proposed drill site and staffed it with a small staff. Between December 2003 and March 2006, InterOil proceeded to cut seismic transects through the long-term study area surrounding the Sera Station but did not drill at all. According to WCS PNG staff, each time they contacted InterOil and asked about the drilling schedule, they were told that drilling would begin shortly.

The presence of InterOil near the Sera Station was not simple or benign. Local landholders began, soon after the camp was established, to visit and to sell food and other items to the small InterOil staff. Local Pawaia and Gimi peoples went to the camp to attempt to make money through these small commodity transactions and through gaining waged labour. They were told, repeatedly, that the staff would eventually hire them when the drilling began. The resident landholders were also told, according to people from Maimafu and Herowana villages, that one of the reasons for the delay in drilling, and thus the delay in waged labour being provided, was the presence of WCS PNG.

Conservation and mining offered the same things to landholders - they made resource extraction and conservation commensurable in people's eyes by tying them both to the promise of 'development' and the social relations that would bring development. But conservation-as-development as a possibility began to fade in local fantasies of the future by the mid-2000s. As WCS worked to establish its office and ongoing presence in PNG and as the resource extraction companies conducted exploration within the CMWMA, the RCF continued with its project of conservation-as-development even in the face of growing dissent among customary landholders who felt they were not getting what they had bargained for when they agreed to work with RCF initially. 


\section{The End of the Crater Mountain Wildlife Management Area}

On 23 March 2006, four Gimi men from Herowana broke into the Sera Research Station with bush knives and guns. The station staff and various WCS PNG researchers and employees working at the station at the time were all in transition between Goroka, Haia (the village one flies into in order to then walk 12 hours to the station) and the station. There was a female researcher at the research station along with her field assistants who were all from Haia village. The four men from Herowana held a gun to her head, beat her and raped her. This vicious attack was the pivotal point in the history of the CMWMA. It was, more importantly, a horrific event for the victim. We write about it here so briefly because we are sensitive to this event not being ours to write about in any detail. However, this kind of 'punitive' rape is one increasingly common form of action in resource extraction situations in PNG. On 25 March 2006 WCS PNG pulled all of their staff out of the CMWMA.

Over the course of the months after the attack, Enock Kale met with people from Herowana to discuss the events that resulted in the violence of 23 March. Members of the Herowana community believed they were not benefiting from the conservation-as-development project. Their main complaint was that they felt that the profits from the project were not being distributed fairly. Initially, instead of blaming WCS, RCF or any of the researchers, they cast blame on Mr Avit Wako, a well-known community leader with historic ties to David Gillison. They argued that he was misusing the income generated from the project, unequally distributing the opportunity for villagers to participate as research assistants and guides, and selectively selling artefacts belonging only to his relatives to visitors. For instance, the villagers complained constantly about Mr Wako not disclosing the money paid as rent by WCS PNG in 2003, which was for bringing in and housing 30 students in the community guest house for one month during their annual biological training courses. The villagers estimated the total amount of money they lost during that training to be more than 10,000 kina. Additionally, many members of the community accused Mr Wako of nepotism with regard to deciding whose coffee bags would be the back load on the MAF (Mission Aviation Fellowship) planes that carried WCS's students and research supplies at a subsidised airfreight cost. The Herowana community viewed Mr Wako as a person who used his power to benefit himself or his relatives at the expense of the community.

Although much frustration was building up, many people could not speak against Mr Wako, because they saw him as intimidating; he would silence whomever he thought was speaking against him, with threats. WCS PNG, RCF and other visitors to Herowana did not find any fault in Mr Wako, because to 
them he was the best man to make logistics possible in the community. He could quickly organise carriers and field assistants for the WCS or RCF if needed. Therefore, according to the local community, he hid his bad deeds from WCS and RCF by promptly attending to their field logistics requirements. This was most likely why WCS was never aware of the complaints and frictions building up against Mr Wako by the Herowana community. These frustrations had even led some villagers to mobilise to construct another airstrip so that they can get away from Mr Wako's influence. The airstrip is almost completed to date.

While the complaints against Mr Wako were building up in Herowana, another land issue was developing between a Herowana family and the clan of Toyaido of the Haia area over the sharing of rent money that WCS was paying for the research site at Sera Research Station. The land on which Sera Research Station was built is rightfully owned by a clan in Toyaido village in the Haia area. It happened that one of the relatives of the clan that owned the land on which the research station was built had migrated to Herowana a long time ago. The descendants of this particular man in Herowana claimed that they were rightful landholders of the Sera Research Station and should therefore be receiving the rent money WCS was paying to the clan in Toyaido. The clan in Toyaido that was receiving the rent acknowledged the claim but provided one condition to the Herowana family before they would share the money: the Herowana man claiming to be the landowner must send one of his sons to be permanently settled in Toyaido with his related clan, and be completely a part of that clan, and then he would be the one with whom they would share the money. Otherwise, if he wanted to claim the money while in Herowana, then the money would not be paid to this man in Herowana or his sons.

The young men of Herowana began to observe the struggles between the community and Mr Wako's influence and decided to rob the Sera Research Station in the hope of disrupting the research activities from which Mr Wako seemed to be benefiting most. The four young men of Herowana who robbed the Sera Research Station and raped the female research scientist on 23 March 2006 were believed to be led by a man who is a direct descendant of the man who migrated to Herowana from the clan in Toyaido, who was also claiming to be the landowner of Sera Research Station but not receiving any rent.

In March 2007, Paige West, along with Robert Bino and John Ericho, the two former directors of the RCF (and both graduates of the WCS PNG training program and honours degree program), went to Maimafu village to hold a 
meeting with its residents to try to help RCF understand its failures. ${ }^{3}$ When they arrived in Maimafu, they found no running water (the RCF-funded water supply system was no longer working), no school, no hospital, no guest house, no radio, limited ability to get coffee to markets, and a very angry mob. This was the first time that Robert and John had been to Maimafu in years. Paige West had been every year and was well aware of the decline there, but they were not. Although neither of them worked with RCF at the time (and indeed John had not worked for them since 2003 and Robert since 2005), people directly blamed John and Robert for the failures of RCF and the decline of the services that they saw as connected to RCF.

At the community meeting, several major concerns were expressed. First, the concern that RCF had 'gotten rich' off 'the Crater name' and that John and Robert had also 'gotten rich' and 'become big men' because of their work with RCF and 'with the Crater name' and that Maimafu's residents had 'gotten nothing' from their social relations with RCF in general and with Robert and John specifically. The second major concern was the failure of RCF to supply development or avenues for development and then totally pull out from the area with no explanation. This is basically the failure of RCF and its staff to participate in the correct way in the Gimi world of exchange relations. Third, people expressed their anger over the perceived opportunities they had missed because of their long-term association with the RCF. They referred to the mining opportunities they perceived missing and the oil-related exploration opportunities they perceived missing. One long-time RCF Management Committee member said:

You told us that RCF would be a 'road to development' but what you have been for all these years now is a roadblock to development. You have stopped us and you have shamed yourself.

While landholders blamed individual actors for the failures of the project, it is our contention that the CMWMA was based on an untested and ultimately flawed hypothesis. Conservation-as-development, the driving ideological force behind the CMWMA, is a neoliberal approach to conservation ecology and economic development, in which it is assumed that environmental conservation can be economic development for rural peoples; that development needs, wants and desires can be met by the protection of 'biodiversity' on their lands, and that if they take part in small-scale income-generation projects that are directly

\footnotetext{
3 In 1994, while still a graduate student, Debra Wright asked WCS to fund a national student, John Ericho, during the research, analysis and writing of his honours thesis. Wright had met Ericho through thenUPNG professor Mike Hopkins. Ericho had been a high school biology teacher and principal at a Seventhday Adventist school in Goroka for years and after meeting Mike Hopkins decided to go back to school to complete an honours degree. He was the first WCS-trained student who went on to be a director of the RCF. $\mathrm{He}$ is currently the national coordinator for the PNG Conservation Forum. Robert Bino worked in Maimafu village for the RCF as a village coordinator. He is currently completing his $\mathrm{PhD}$ in resource management at The Australian National University. He is not writing about the CMWMA.
} 
connected to this 'biodiversity' they can seamlessly enter 'global markets' as producers and consumers, while at the same time working to conserve 'biodiversity' for the supposed good of the entire planet. These policies and practices, designed and implemented by NGOs, are meant to both conserve the natural world and provide cash income so that people living where state services have retreated can pay for basic needs like education, health care and subsistence. The projects also move the management and legislation of the relations between people, their surroundings and the market into the purview of NGOs. These eco-neoliberal practices and policies attempt to meet the social and economic needs of rural peoples through fostering, facilitating and supporting the retreat of the state and putting private industry and NGOs in its place. In the CMWMA the material and social consequences of these policies in and around rural villages have been that both people and the environment are left worse off as a result of their implementation.

Since the entire conservation area was based on the premise, from $\mathrm{BCN}$, that conservation would bring people economic benefits, the project also, from its inception, was directly in competition with resource extraction. By connecting biodiversity to the global economic system, the architects of the CMWMA made conservation and mining commensurable. Residents of the CMWMA saw the two as equally valid options for economic and social betterment. They weighed their options, and chose the one that appeared to make the promise of more future benefits.

The CMWMA was also based on an erroneous set of assumptions about subjectivity that outsiders brought with them to their interactions with Gimi and the assumptions that Gimi had about outsiders. During the life of the CMWMA the incommensurable understandings of social relations and what those relationships meant held by conservation actors and Gimi peoples posed a barrier to true collaboration and understanding. For conservation planners and practitioners the conservation-as-development project established a contract between themselves and Gimi. In this contract, outsiders understood that they would get conservation, in the form of the curtailment of hunting practices and land clearing practices, and the allowing of access to Gimi territory in exchange for development, which took the form of cash income for Gimi based on ecotourism, handicraft sales and waged labour positions working for visiting scientists. Gimi, whose indigenous epistemology turns on the idea that all things come into being through exchange and that exchange relationships are in constant need of maintaining, understood the social relations they were entering into as enduring ones in which they would contribute land, labour, food and friendship to the conservation practitioners and that these contributions would be reciprocated in socially appropriate ways. They understood these social relationships as allowing them access to medicine, education, technology, 
knowledge and wealth - the things that they think of as 'development'. Through ethnographic evidence we demonstrate that this was not simply a set of misunderstandings but that these differences in the perception of reality illustrate different ways of being in and making the world. The conservation project's ultimate failure was not the result of people not holding up their end of the bargain; rather, people had been, for the duration of their social interactions, taking part in radically different social worlds.

These different social worlds also extend to the natural world or the Gimi forests. For Gimi, everything in the forest is a gift as it is the physical incarnation of their ancestors' life force. People and forests will always be - and have always been — in a constant transactive relationship, making and remaking each other over time. The Gimi world and Gimi as subjects and agents are produced through social relationships between people, ancestors, spirits and animals. These social relations are not neutral and economic; they are familial and poetic. People's capacities are seen as they relate to other people, to plants, to animals, to spirits and to ancestors, and their social selves are understood as comprising the sources that went into making them. So what is translated as 'the Gimi environment' by conservation practitioners is not simply a place filled with floral and faunal resources waiting to be used or made into commodities, it is the generative place of the social world. By treating Gimi forests as 'the environment', conservation practitioners not only misunderstood Gimi but also predestined their project for failure from the very beginning. The entire conservation-as-development project was based on ideas about nature and culture that define Gimi as rational economic actors who value forests because of their potential as commodities and status as resources. This assumption formed the basis for interventions specifically ecotourism, handicraft production and attempts to regulate hunting practices - that have transformed society and space.

It was of no surprise to people familiar with the CMWMA that by $2006 \mathrm{RCF}$ was seen as a total and complete failure in the eyes of the majority of landholders around Crater Mountain. In January 2006, RCF 'pulled out' of the Crater Mountain area completely. They flew their staff out of the villages without providing any explanations to the villagers and left without a trace. This quick exit was due, according to official emails and press releases, to the organisation's failure to raise funds for site-based conservation and development projects and its shift to primary and high school conservation-related education as a main focus. 


\section{The Fate of WCS in PNG and PNG in WCS}

On Friday 9 March 2007, Paige West called Debra Wright to discuss an upcoming trip to PNG. When she answered the phone, Wright told West that WCS had terminated her and Mack's employment and that the fate of the WCS PNG program was completely up in the air. Over the course of the next six months various stories emerged about why Mack and Wright had been terminated.

The initial story given publicly about the Mack and Wright dismissal was that WCS had decided to 'pull out' of PNG totally. Various conservation-related actors were told that the country program was 'too expensive' and that WCS needed its limited resources elsewhere. When word began to spread that Mack and Wright had been fired, WCS began to receive outraged emails, faxes and phone calls from people all over the world. It received angry communications from well-known people: Sir Michael Somare (PNG's prime minister), Mal Smith (the governor of Eastern Highlands Province) and the Biology Department at UPNG. WCS also received hundreds of communications from scientists, social scientists and others who have worked in PNG over the years. The majority of these communications stressed the success of the Mack/Wright training program and voiced outrage over WCS's closing of its PNG office.

By mid-March 2007, the public story about the future of WCS PNG began to change. WCS International sent the assistant director of its Asia Program, a man who had never been to PNG before, and a WCS accountant to Goroka to meet with the WCS national staff to discuss 'the way forward'. These discussions resulted in Miriam Supuma and Banak Gamui, two WCS PNG employees from PNG who had been through the training program, the honours program, and successfully completed masters degrees (Supuma at James Cook University and Gamui at the University of Missouri), being named the 'co country directors' of WCS PNG. Supuma and Gamui were, over the next six months, slowly told that the education program at WCS PNG was to be phased out. The current students would be allowed to finish, but 'WCS is not a University' and Supuma and Gamui would be in charge of shifting the focus of the organisation to site-based conservation.

In an interview about the end of the WCS PNG training program, one very senior conservation biologist who has worked extensively in PNG told West:

I would say any organization like WCS that has been in a country for twenty years has been there too long. They should be able to build the sort of national capacity needed in under twenty years if they really try, even in a place as backward (in terms of scientific capacity) as PNG. These big organizations, I think, see that attitude as some sort of threat to themselves. They don't really want to build a national capacity that will make them obsolete. I'm not sure I would call that 
'neocolonialism' but maybe I would say they are subconsciously driven by unenlightened self-interest. After all these years of international conservation, WCS should have programs winking out around the world as national NGOs and government agencies take over. WCS could then concentrate on other countries and eventually, in an ideal world, be mostly focused on North America.

When they boast that they are committed to conservation in these places indefinitely, I see that as a flaw, not a worthy attribute. They should be boasting that they will not be needed indefinitely ... that they will measure success not by how long they stay, but by how quickly they can leave.

\section{Rebirth: The Papua New Guinea Institute for Biological Research}

On 13 February 2008 the following notice appeared in both the Post-Courier and The National, the two major newspapers in PNG:

\section{NOTICE OF INTENTION TO APPLY FOR THE INCORPORATION OF AN} ASSOCIATION

I, Ms Miriam Supuma of Goroka, P.O. Box 277, EHP, a person authorized for the purpose by the committee of the association known as Papua New Guinea Institute of Biological Research, give notice that I intend to apply for the incorporation of the association under the Associations Incorporation Act 1966.

The following are the details of the prescribed qualifications for incorporation as specified in Section 2 of the Act:

(a) To be a premier research institution for conducting biological research and monitoring on the flora and fauna of Papua New Guinea; and

(b) To provide an avenue for national and overseas scientists to conduct biological research and monitoring to advance scientific knowledge in Papua New Guinea. We will do this conducting our own research and by aiding other scientists to conduct their research whenever possible, and by presenting our findings in an accessible manner to the scientific community, to the public, and to policy makers; and

(c) To provide a conducive learning environment for capacity building by training aspiring national biologists, including those currently attending universities as undergraduates or graduates and those already working as professional biologists and conservationists in the non-profit, government, or private sectors. We will do this by bringing in internationally recognized scientists to teach training courses and to give trainees first hand experience with biological surveys, research techniques, data analyses and scientific writing; and 
(d) To source funding from national and international donor agencies to conduct biological research and monitoring, to train university students and conservation professionals to conduct biological research and monitoring, and to conduct seminars, education and awareness on biological knowledge and conservation in PNG; and

(e) To facilitate opportunities for university students and conservation professionals to attend short training courses, workshops and scientific meetings both in PNG and abroad and to further their careers through Honours, Masters and PhD degrees in PNG or at overseas institutions; and

(f) To collaborate with national and overseas universities, museums and other research institutions to conduct biological research in PNG and overseas and arrange for exchange programs to train PNG university students and conservation professionals; and

(g) To assist PNG university students and conservation professionals in terrestrial and marine biology, environmental science, forestry and agriculture to design and conduct appropriate biological research of high quality and of international standards; and

(h) To use our research data to develop recommendations for the sustainable management of PNG's fauna and flora and to present these recommendations to landowners, resources users, conservation managers, the government and other stakeholders to aid them in making wise decisions; and

(i) To build and maintain biological research station(s) where research will be done and collaborate with partner organizations on the use and management of the research station(s); and

(j) To produce and distribute papers, report and publications, media releases etc. on the research and work we do; and

(k) To plan and facilitate work both on advisory and consultancy basis; and

(l) To apply profits (if any) or any income in promoting the Association's objectives; and

(m) To prohibit the payment of dividends or payment in nature of dividend to its members; and

(n) To do generally all such other things that may appear to be incidental to or conducive to the attainment of the Association's objectives or any of the above.

After WCS International sent the assistant director of the Asia Program to PNG to sort out what to do with WCS PNG after the termination of Debra Wright and Andrew Mack, the senior Papua New Guinean staff of WCS PNG felt unsettled. In the initial discussions, even after two national ecologists (Miriam Supuma and Banak Gamui) were made co-directors of WCS PNG, WCS International argued 
that there had to be an expatriate advisor to the program. WCS International also argued that WCS PNG should be focused on site-based conservation and the creation of new protected areas. The senior staff of WCS PNG, all Papua New Guinean, felt strongly that the creation of new protected areas is not the appropriate strategy for fostering conservation in the country. They all saw the continuation of the training courses and the honours degree program as crucial for building a national conservation strategy. One of the staff, when asked why they all felt so strongly that the site-based conservation focus of the international program was a problem, said:

I don't mean to disparage America, but protected areas is American and this is Papua New Guinea. With land ownership here, we can't alienate land. We need to figure out how to conserve our land ourselves and the way to do that is to produce more scientists from here. Scientists who know the place and the people and who know their science.

Because of this shared sentiment among the WCS PNG senior staff, they decided to form a new Papua New Guinean NGO and continue the training courses and honours degree program.

\section{Conclusions}

In this chapter we have described the history of the CMWMA and some of the reasons for its decline. We have also described one of the 'conservation success stories' to come out of the CMWMA and its decline. We showed that the project had very informal beginnings in the 1970s but that over the course of the 1980s and 1990s its architects worked to solidify it spatially and legally under Papua New Guinean law. We then showed that in the late 1990s the project was incorporated into a large international 'experiment' meant to test the hypothesis that market or enterprise-oriented approaches to conservation are effective if indigenous peoples are given labour connected to conservation and if they are encouraged to commoditise biological diversity in particular kinds of ways. Next we described in detail a program for science training and education for national scientists that grew out of the CMWMA. Finally, we discussed the demise of the CMWMA and of the training program, highlighting the material and ideological reasons for these declines. It is our contention that the CMWMA was based on a fatally flawed set of ideas and that it was carried out as if larger political-economic drivers were not conterminously affecting landholder life and politics as the CMWMA was being developed. The living legacy today of the CMWMA is the PNG Institute for Biological Research. This NGO has facilitated the growth of national science in the country and 
created a generation of national scientists and conservationists. It is also our contention that conservation projects developed by these actors will outperform interventions like the CMWMA.

\section{References}

BSP (Biodiversity Support Program), 1996. Biodiversity Conservation Network 1996 Annual Report: Stories from the Field and Lessons Learned. Washington: BSP.

Ellis, D.M., 2002. Between Custom and Biodiversity: Local Histories and Market-Based Conservation in the Pio-Tura Region of Papua New Guinea. Canterbury: University of Kent, Department of Anthropology (PhD thesis).

Ellis, D.M. and P. West, 2004. 'Local History as "Indigenous Knowledge": Aeroplanes, Conservation and Development in Haia and Maimafu, Papua New Guinea.' In A. Bicker, P. Sillitoe and J. Pottier (eds), Investigating Local Knowledge: New Directions, New Approaches. London: Ashgate Publishing.

Johnson, A., 1997. 'Processes for Effecting Community Participation in the Establishment of Protected Areas: A Case Study of the Crater Mountain Wildlife Management Area.' In C. Filer (ed.), The Political Economy of Forest Management in Papua New Guinea. Boroko: National Research Institute (Monograph 32).

Mack, A. and P. West, 2005. 'Ten Thousand Tonnes of Small Animals: Wildlife Consumption in Papua New Guinea, a Vital Resource in Need of Management.' Canberra: The Australian National University, Resource Management in Asia-Pacific Program (Working Paper 61).

Macmin Silver Ltd, 1997. 'E.L.1115 Crater Mountain Site Report.' Unpublished manuscript.

Macmin Silver Ltd, 2000. 'Macmin N.L. Current Projects Crater Mountain.' News Release, 9 February.

Majnep, I.S. and R. Bulmer, 1977. Birds of My Kalam Country. Auckland: Auckland University Press.

Majnep, I.S. and R. Bulmer, 2007. Introduction. In I.S. Majnep, R. Bulmer, R. Hide and A. Pawley (eds), Animals the Ancestors Hunted: An Account of the Wild Mammals of the Kalam Area, Papua New Guinea. Adelaide: Crawford House Publishing. 
NGG (New Guinea Gold), 2002. 'New Guinea Gold Corporation (the Company) to Acquire up to $100 \%$ Ownership of Seven Papua New Guinea Gold \& Gold/ Copper Projects.' News Release, 12 June.

NGG (New Guinea Gold), 2004. 'Crater Mountain Trenching Returns High Gold Results.' News Release, 5 February.

Post-Courier, 2004a. 'Macmin Silver Ltd. Signs Joint Venture Agreement with Celtic Minerals Ltd.' Post-Courier, 6 January.

Post-Courier, 2004b. 'High Gold Results at Crater Mountain.' Post-Courier, 9 February.

West, P., 2001. 'Environmental Non-Governmental Organizations and the Nature of Ethnographic Inquiry.' Social Analysis 45(2): 55-77.

West, P., 2003. 'Knowing the Fight: The Politics of Conservation in Papua New Guinea.' Anthropology in Action: Journal for Applied Anthropology in Policy and Practice 10(2): 38-45.

West, P., 2004. 'Environmental Non-Governmental Organizations and the Nature of Ethnographic Inquiry.' In P. Stewart and A. Strathern (eds), Anthropology and Consultancy: Issues and Debates. New York and Oxford: Berghahn Books.

West, P., 2005a. 'Holding the Story Forever: The Aesthetics of Ethnographic Labor.' Anthropological Forum 15(3): 267-75.

West, P., 2005b. 'Translation, Value, and Space: Theorizing an Ethnographic and Engaged Environmental Anthropology.' American Anthropologist 107(4): $632-42$.

West, P., 2006a. Conservation Is Our Government Now: The Politics of Ecology in Papua New Guinea. Durham (NC): Duke University Press.

West, P., 2006b. 'Environmental Conservation and Mining: Between Experience and Expectation in the Eastern Highlands of Papua New Guinea.' The Contemporary Pacific 18(2): 295-313.

West, P., 2008a. 'Conservation Actions and Events in Papua New Guinea.' In B.B. Walters, B.J. McCay, P. West and S. Lees (eds), Against the Grain: The Vayda Tradition in Human Ecology and Ecological Anthropology. Lanham (MD): AltaMira Press.

West, P., 2008b. 'Scientific Tourism: Imagining, Experiencing, and Portraying Environment and Society in Papua New Guinea.' Current Anthropology 49(4): 597-626. 
West, P. and D. Brockington, 2006. 'An Anthropological Perspective on Some Unexpected Consequences of Protected Areas.' Conservation Biology 20(3): 609-16.

West, P. and J.G. Carrier, 2004. 'Ecotourism and Authenticity: Getting Away from It All?' Current Anthropology 45(4): 483-98.

West, P., J. Igoe and D. Brockington, 2006. 'Parks and Peoples: The Social Impact of Protected Areas.' Annual Review of Anthropology 35: 251-77. 
This text is taken from Tropical Forests of Oceania: Anthropological Perspectives, edited by Joshua A. Bell, Paige West and Colin Filer, published 2015 by ANU Press, The Australian National University, Canberra, Australia. 